\title{
A comparative study of serum calcium, magnesium and LDH as the best predictor for severity of pregnancy induced hypertension in the rural population
}

\author{
Mehul Salve*, Aditi Rajgire
}

Department of Obstetrics and Gynaecology, Acharya Vinoba Bhave Institute of Medical Sciences, Sawangi, Meghe, Maharashtra, India

Received: 15 August 2017

Accepted: 19 September 2017

\author{
*Correspondence: \\ Dr. Mehul Salve, \\ E-mail: mehulsalve@gmail.com
}

Copyright: (c) the author(s), publisher and licensee Medip Academy. This is an open-access article distributed under the terms of the Creative Commons Attribution Non-Commercial License, which permits unrestricted non-commercial use, distribution, and reproduction in any medium, provided the original work is properly cited.

\begin{abstract}
Background: Hypertensive disorders of pregnancy are one of the commonly encountered problem by obstetrician of which, pregnancy induced hypertension leads the list. A number of dietary deficiencies or excesses have been blamed as the cause for preeclampsia over centuries. Studies have shown relationship between dietary deficiencies and incidence of preeclampsia. The lowering of serum calcium and the increase of intracellular calcium can cause an elevation of blood pressure in preeclamptic mothers. Recent investigations suggest that magnesium deficiency could play an important role in the pathogenesis of preeclampsia, particularly in regulating the tonus of arterioles and veins. The relationship of serum leptin and lactate dehydrogenase levels were increased in preeclampsia.

Methods: A comparative study to evaluate the levels of serum calcium and serum magnesium and LDH in pregnancy induced hypertension and normal pregnancy and to correlate the serum levels of calcium and magnesium and LDH with the pregnancy induced hypertension.

Results: The serum calcium and magnesium has significantly decreased in cases as compared to controls. Whereas the levels of LDH was significantly increased in cases compared to controls. Serum calcium decreased in severe PIH cases compared to mild PIH cases but statistically not significant. Serum magnesium in mild PIH is less compared to severe PIH cases. The decrease is not statistically significant. The increase in LDH in mild case is less compared to severe PIH case. The increase is stastically significant.

Conclusion: Routine biochemical evaluation of serum concentration of calcium and magnesium early in pregnancy may be helpful in identifying at risk patients for preeclampsia. Hypocalcemia and Hypomagnesemia in patients with pregnancy induced hypertension may have a cause and effect relationship with the disorder. Amongst the biochemical markers studied LDH level was seen as the best predictor of severity of pregnancy induced hypertension.
\end{abstract}

Keywords: Lactate dehydrogenase, Pregnancy induced hypertension

\section{INTRODUCTION}

Hypertensive disorders of pregnancy are one of the commonly encountered problem by obstetrician of which, pregnancy induced hypertension leads the list. Other causes being gestational hypertension, essential hypertension, secondary hypertension. It is responsible for significant maternal and foetal morbidity and mortality. It is estimated that upto $30 \%$ of perinatal deaths are related to hypertensive disorders of pregnancy. ${ }^{1}$

The etiology of pregnancy induced hypertension is unknown. A number of dietary deficiencies or excesses have been blamed as the cause for preeclampsia over centuries. Studies have shown relationship between 
dietary deficiencies and incidence of preeclampsia. Some studies conclude malnutrition as risk factor in the etiology of preeclampsia because of its higher incidence in developing countries and implicate it by deficit in the intake of calcium, magnesium, Zinc. Epidemiologic data show an inverse relationship between calcium intake and pregnancy induced hypertension. Calcium supplementation can lower blood pressure and reduce the incidence of preeclampsia in pregnant women. ${ }^{2-4}$

Pregnancy entails number of physiological events with implications regarding calcium metabolism: the extracellular fluid expands, the albumin level decreases, the glomerular filtration rate increases causing increase in calciuria and calcium is removed from the maternal system by transfer to fetus. Modification of plasma calcium concentration leads to alteration of blood pressure. The lowering of serum calcium and the increase of intracellular calcium can cause an elevation of blood pressure in preeclamptic mothers. ${ }^{5}$

There is decrease in ionized and total magnesium levels with increasing gestational age during normal pregnancy. Magnesium levels may have significant effects on cardiac excitability and on vascular tone, contractility and reactivity. Magnesium causes vascular muscle relaxation. ${ }^{6,7}$ Recent investigations suggest that magnesium deficiency could play an important role in the pathogenesis of preeclampsia, particularly in regulating the tonus of arterioles and veins (Seelig et al). ${ }^{8}$

Pregnancy induced hypertension is characterised by vasospasm, elevated blood pressure and increased neuro muscular irritability, features common to syndromes of magnesium deficiency. ${ }^{9}$

LDH is a protein that normally appears throughout the body in small amounts. Tissue breakdown releases LDH, and therefore $\mathrm{LDH}$ can be measured as a surrogate for tissue breakdown, e.g. hemolysis. Increase in $\mathrm{LDH}$ is predictive of small for gestational age infants in preeclamptic pregnancy, especially in those with normal liver function. He also concluded that the elevated serum leptin levels in preeclampsia indicate endothelial dysfunction involved in the pathogenesis of preeclampsia. The relationship of serum leptin and lactate dehydrogenase levels were increased in preeclampsia that is directly proportional to gestational age in last trimester. These biochemical parameters were significantly elevated in severe preeclampsia, mild preeclampsia and compared to normal pregnancy. ${ }^{10}$

Normal reference range of serum lactate dehydrogenase during pregnancy are as follows:

- Non-pregnant adults: 115-211 IU

- First trimester: 78-433 IU

- Second trimester: 80-447 IU

- Third trimester: 82-524 IU.
The objectives of this study were to evaluate cases of pregnancy induced hypertension, to estimate the serum calcium, magnesium and LDH levels in normal pregnancy and pregnancy induced hypertension, comparison of the serum calcium, magnesium and LDH in pregnancy induced hypertension with the levels in normal pregnancy and correlating the values of serum calcium, magnesium and $\mathrm{LDH}$ as a predictor of severity of pregnancy induced hypertension.

\section{METHODS}

A comparative study to evaluate the levels of serum calcium and serum magnesium and LDH in pregnancy induced hypertension and normal pregnancy. To correlate the serum levels of calcium and magnesium and LDH with the pregnancy induced hypertension.

\section{Inclusion criteria}

Study group

A total of 100 diagnosed cases of pregnancy induced hypertension with more than 20 weeks gestational age with singleton pregnancy were included in the study group.

\section{Control group}

A total of 100 women without pregnancy induced hypertension with comparable parameters with the study group were included in the control group.

\section{Exclusion criteria}

- Chronic hypertension and history of preeclampsia in previous pregnancy

- Gestational diabetes mellitus

- Renal disease

- Multifetal gestation.

\section{RESULTS}

A comparative clinical study (case-control study) with a total of 200 patients was carried out in Department of Obstetrics and Gynaecology, at Jawaharlal Nehru Medical College, Sawangi (Meghe), Wardha.

\section{Serum calcium, serum magnesium and $\mathrm{LDH}$ in two groups}

Table 1 shows concentration of serum calcium in control as $9.16 \pm 0.81$ and in study group $8.15 \pm 0.37 \mathrm{mg} / \mathrm{dl}$ with $\mathrm{p}$ value $<0.001$. The serum magnesium levels in control $2.08 \pm 0.46$ and in study group as $1.78 \pm 4.70 \mathrm{mEq} / \mathrm{L}$ with $\mathrm{p}$ value 0.013 . The $\mathrm{LDH}$ value in the control group is $261.18 \pm 116.07$ and in the study group $1046.45 \pm 648.49$ is with the $\mathrm{p}$ value of 0.0001 . The serum calcium and magnesium has significantly decreased in cases as 
Table 1: Comparison of serum calcium and serum magnesium and LDH levels in PIH and normotensives.

\begin{tabular}{|llll}
\hline Outcome variables & Control groujp & Study group & P value \\
\hline Serum calcium $(\mathrm{mg} / \mathrm{dl})$ & $9.16 \pm 0.82(7.80-12.00)$ & $8.15 \pm 0.37(7.20-9.00)$ & $<0.001, \mathrm{~S}$ \\
\hline Serum magnesium $(\mathrm{mEq} / \mathrm{L})$ & $2.08 \pm 0.46(1.30-3.10)$ & $1.78 \pm 0.70(1.00-4.70)$ & $0.013, \mathrm{~S}$ \\
\hline LDH $(\mathrm{IU})$ & $261.18 \pm 116.07$ & $1046.45 \pm 648.49$ & 0.0001 \\
\hline
\end{tabular}

NS = non-significant, $\mathrm{S}=$ significant

\section{Serum calcium and serum magnesium and $\mathrm{LDH}$ in mild and severe PIH cases}

Serum calcium in mild pregnancy induced hypertension is $8.17 \pm 0.38 \mathrm{mg} / \mathrm{dl}$ and in severe pregnancy induced hypertension is $8.12 \pm 0.36 \mathrm{mg} / \mathrm{dl}$ with $\mathrm{p}$ value 0.668 . Serum calcium decreased in severe PIH cases compared to mild PIH cases but statistically not significant. Serum magnesium in mild $\mathrm{PIH}$ case is $1.67 \pm 0.53 \mathrm{mEq} / \mathrm{L}$ and in severe $\mathrm{PIH}$ case $1.97 \pm 0.92 \mathrm{mEq} / \mathrm{L}$ with $\mathrm{p}$ value 0.157 . Serum magnesium in mild PIH is less compared to severe $\mathrm{PIH}$ cases. The decrease is not statistically significant. Serum LDH in mild PIH case is IU and in severe PIH case is IU with $p$ value of. The increase in LDH in mild case is less compared to severe PIH case. The increase is stastically significant.

Table 2: Comparison of serum calcium and serum magnesium in mild and severe PIH cases.

\begin{tabular}{|llll|}
\hline Outcome variables & PIH & Mevere & P value \\
\hline Serum calcium $(\mathrm{mg} / \mathrm{dl})$ & $8.17 \pm 0.38(7.20-8.80)$ & $8.12 \pm 0.36(7.70-9.00)$ & $0.668, \mathrm{NS}$ \\
\hline Serum $\mathrm{Mg}(\mathrm{mEq} / \mathrm{L})$ & $1.67 \pm 0.53(1.00-2.90)$ & $1.97 \pm 0.92(1.00-4.70)$ & $0.157, \mathrm{NS}$ \\
\hline LDH & $618.48 \pm 169.65 \mathrm{IU}$ & $1046.45 \pm 648.49 \mathrm{IU}$ & $0.0001, \mathrm{~S}$ \\
\hline
\end{tabular}

$\mathrm{NS}=$ non-significant; results are presented as Mean \pm SD (min-max)

\section{DISCUSSION}

In this study, the serum concentration of calcium in normal pregnancy is $9.16 \pm 0.82 \mathrm{mg} / \mathrm{dl}$, in mild $\mathrm{PIH}$ cases $8.17 \pm 0.38 \mathrm{mg} / \mathrm{dl}$, in severe PIH cases $8.12 \pm 0.36 \mathrm{mg} / \mathrm{dl}$ Table 3. Serum calcium is decreased in both severe PIH and mild PIH cases compared to normal pregnancy. Calcium is significantly not decreased with increased severity of PIH. The present study results were comparable to study of Punthumapol $\mathrm{C}$ et al and Jain $\mathrm{S}$ et al. ${ }^{11,12}$

Table 3: Comparison of serum calcium in normal pregnancy, mild PIH and severe PIH cases.

\begin{tabular}{|llll} 
Studies & $\begin{array}{l}\text { Normal } \\
\text { Pregnancy } \\
(\mathrm{mg} / \mathrm{dl})\end{array}$ & $\begin{array}{l}\text { Mild } \\
\text { PIH } \\
(\mathrm{mg} / \mathrm{dl})\end{array}$ & $\begin{array}{l}\text { Severe } \\
\text { PIH } \\
(\mathrm{mg} / \mathrm{dl})\end{array}$ \\
\hline $\begin{array}{l}\text { Punthumapol C } \\
\text { et al }{ }^{10}\end{array}$ & $8.99 \pm 0.31$ & $9.05 \pm 0.52$ & $8.70 \pm 0.59$ \\
\hline Present study & $9.16 \pm 0.82$ & $8.17 \pm 0.38$ & $8.12 \pm 0.36$ \\
\hline
\end{tabular}

In this study, serum concentration of magnesium in normal pregnancy is $2.53 \pm 0.56 \mathrm{mg} / \mathrm{dl}$, in mild $\mathrm{PIH}$ $2.03 \pm 0.64 \mathrm{mg} / \mathrm{dl}$, in severe PIH $2.40 \pm 0.62 \mathrm{mg} / \mathrm{dl}$ (Table 3 ). Serum magnesium is decreased in mild and severe PIH cases compared to normal pregnancy. Serum magnesium is increased in severe PIH cases compared to mild PIH cases. Serum magnesium levels did not correlate with the severity of PIH.

Table 2: Comparison of serum magnesium in normal pregnancy, mild PIH, severe PIH cases.

\begin{tabular}{|llll|}
\hline Studies & $\begin{array}{l}\text { Normal } \\
\text { Pregnancy } \\
(\mathrm{mg} / \mathrm{dl})\end{array}$ & $\begin{array}{l}\text { Mild } \\
\text { PIH } \\
(\mathrm{mg} / \mathrm{dl})\end{array}$ & $\begin{array}{l}\text { Severe } \\
\text { PIIH } \\
(\mathrm{mg} / \mathrm{dl})\end{array}$ \\
\hline $\begin{array}{l}\text { Punthumapol C } \\
\text { et al }{ }^{10}\end{array}$ & $2.04 \pm 0.19$ & $2.04 \pm 0.21$ & $2.24 \pm 0.62$ \\
\hline Present study & $2.53 \pm 0.56$ & $2.03 \pm 0.64$ & $2.40 \pm 1.12$ \\
\hline
\end{tabular}

This study result is comparable with studies that have suggested possible role of serum Lactic dehydrogenase (LDH) in the pathogenesis of preeclampsia. Elevated levels of serum LDH indicate the tissue damage related to endothelial dysfunction and endovascular which are main causes of occurrence of preeclampsia (Sarkar et al). ${ }^{13}$ Therefore, serum LDH level seems promising, as it fulfils most criteria for an ideal biomarker, because it is inexpensive, quickly estimable easily available biomarker enabling early identification of preeclampsia, which in turn can predict severity and outcome, can be very helpful in lowering the maternal and fetal morbidity and mortality. It also is known to rise early in the course of preeclampsia (Dave et a1). ${ }^{14}$ However, results from various studies designed to test the usefulness of $\mathrm{LDH}$ in 
preeclampsia have not been fully consistent. Nosrat et al and Punthumapol $\mathrm{C}$ et al. ${ }^{11,15}$

\section{CONCLUSION}

From the foregoing discussion, following conclusions can be drawn

- The serum calcium and serum magnesium levels are decreased in pregnancy induced hypertension patients compared to normotensive pregnant women

- The increase of serum calcium with increase in gestational age and the decrease in serum magnesium with increased albuminuria was moderately significant

- The present study suggests hypocalcemia and hypomagnesemia could be possible contributors in the etio-pathophysiology of pregnancy induced hypertension

- A routine biochemical evaluation of serum concentration of calcium and magnesium early in pregnancy may be helpful in identifying at risk patients for preeclampsia. Hypocalcemia and hypomagnesemia in patients with pregnancy induced hypertension may have a cause and effect relationship with the disorder

- Amongst the biochemical markers studied LDH level was seen as the best predictor of severity of pregnancy induced hypertension compared to serum calcium and magnesium.

\section{ACKNOWLEDGMENTS}

Authors would like to thank the institute to allow them to carry out this study and women who participated in this study.

Funding: No funding sources Conflict of interest: None declared

Ethical approval: The study was approved by the Institutional Ethics Committee

\section{REFERENCES}

1. WHO. The hypertensive disorders of pregnancy. WHO Tech Rep Ser. 1987;758:93-4.

2. Belijan JM, Villar J. The relationship between calcium intake and edema-proteinuria, and
Hypertension-gestosis: An Hypothesis. Am J Clin Nutrition. 1980;33:2202-10.

3. Carroli G, Duley L, Belijan JM, Villar J. Calcium supplementation during pregnancy: a systematic review of randomised controlled trials. $\mathrm{Br} \mathrm{J}$ Obstetrics Gynecol. 1994;101:753-8.

4. Caughey AB, Stotland NE, Washington AE, Escobar GJ. Maternal ethnicity, paternal ethnicity and paternal ethnic discordance; Predictors of preeclampsia. Obstet Gynecol. 2005;106:156-61.

5. Ray J, Vasishta K, Kaur S, Majumdar S, Sawhney H. Calcium metabolism in preeclampsia. Int J Gynaecol Obstet. 1999;66:245-50.

6. Tong GM, Rude RK. Magnesium deficiency in critical illness. J Intensive Care Med. 2005;20:3-17.

7. Touy ZRM. Role of Magnesium deficiency in pathogenesis of hypertension. Mol Aspects Med. 2003;24:107-36.

8. Seydoux J, Girardin E, Paunier L, Beguin F. Serum and intracellular magnesium during normal pregnancy and in patients with preeclampsia. $\mathrm{Br} \mathbf{J}$ Obstet Gynecol. 1992;99:207-11.

9. Sanders GT, Heink J, Huijgen. Magnesium in disease. Clinical Chemistry Laboratory Med. 1999;37(11-12):1011-33

10. Punthuinapol C, Kittichotpanich B. Serum calcium, magnesium and uric acid in preeclampsia and normal pregnancy. J Med Assoc Thai. 2008;91(7):968-73.

11. Jain S, Sharma P, Shobha K, Mohan G, Singh S. The role of calcium and magnesium and zinc in preeclampsia. Biological trace element Research 2009.

12. World Health Organization. The World Health Report 1998: life in the $21^{\text {st }}$ century; a vision for all. Geneva. WHO. 1998:97.

13. Bodnar LM, Simhan HN, Catov JM. Maternal vitamin D status and the risk of mild and severe preeclampsia. Epidemiol (Cambridge, Mass). 2014;25(2):207-14.

14. Roberts JM, Gammill HS. Preeclampsia: recent insights. Hypertension. 2005;46(6):1243-9.

Cite this article as: Salve M, Rajgire A. A

comparative study of serum calcium, magnesium and LDH as the best predictor for severity of pregnancy induced hypertension in the rural population. Int $\mathbf{J}$ Reprod Contracept Obstet Gynecol 2017;6:4652-5. 